Canadian University Music Review

Revue de musique des universités canadiennes

Robert P. Morgan, ed. Modern Times: From World War I to the

Present. Englewood Cliffs, N.J.: Prentice Hall, 1994. x, 464 pp.

ISBN 0-13-590134-0 (hardcover), ISBN 0-13-590159-6 (paperback)

\title{
Clark Ross
}

Volume 16, numéro 2, 1996

URI : https://id.erudit.org/iderudit/1014433ar

DOI : https://doi.org/10.7202/1014433ar

Aller au sommaire du numéro

\section{Éditeur(s)}

Canadian University Music Society / Société de musique des universités canadiennes

\section{ISSN}

0710-0353 (imprimé)

2291-2436 (numérique)

Découvrir la revue

Citer ce compte rendu

Ross, C. (1996). Compte rendu de [Robert P. Morgan, ed. Modern Times: From World War I to the Present. Englewood Cliffs, N.J.: Prentice Hall, 1994. x, 464 pp. ISBN 0-13-590134-0 (hardcover), ISBN 0-13-590159-6 (paperback)]. Canadian

University Music Review / Revue de musique des universités canadiennes, 16(2), 128-131. https://doi.org/10.7202/1014433ar

All Rights Reserved (C Canadian University Music Society / Société de musique des universités canadiennes, 1996
Ce document est protégé par la loi sur le droit d'auteur. L’utilisation des services d'Érudit (y compris la reproduction) est assujettie à sa politique d'utilisation que vous pouvez consulter en ligne.

https://apropos.erudit.org/fr/usagers/politique-dutilisation/ 
under discussion. Each book presents an extremely helpful chronology that lines up important events and dates for music, politics, literature, science, and visual art. The indices appear to be quite complete, and thus are very useful. Users should be aware, however, that institutions and performance facilities normally do not receive separate index entries, but rather are indexed under their respective city. ${ }^{14}$

One note in passing, about Canadian content, which-while by no means a prerequisite for a successful social history of music-nevertheless should be considered in the context of this journal. The United States receives complete treatments in articles in both volumes, larger Latin-American countries such as Mexico, Cuba, Brazil, and Argentina are also covered in some detail for the entire 19th century, and there are even short paragraphs about music in smaller countries like Peru, Bolivia, and Uruguay. In this light, the complete absence of any treatment of Canada, whether as a country or as represented by its leading urban centres Toronto and Montreal, is puzzling. While it is true that Canadian musical culture had yet to develop a unique voice during the nineteenth century, the significance of musical production under distinctive conditions from Europe or the United States and the emergence of isolated attempts at giving expression to the Canadian experience in music should warrant inclusion of Canada in future editions of the series' nineteenth-century volumes.

The two Romantic-Era volumes of Music and Society are essential reading for anyone who deals with nineteenth-century music, whether as performer, audience member, researcher, or teacher. The various articles inform us well about the conditions under which the specific music we play, hear, study, and teach arose. Moreover, the very existence of this series can be regarded as testifying to the social foundations of music in general. Perhaps upon the basis of recognizing music in society we can also begin to understand the more problematic, yet potentially equally rewarding, concept of society in music.

James Deaville

Robert P. Morgan, ed. Modern Times: From World War I to the Present. Englewood Cliffs, N.J.: Prentice Hall, 1994. x, 464 pp. ISBN 0-13-590134-0 (hardcover), ISBN 0-13-590159-6 (paperback).

1. Robert P. Morgan, "The Modern Age"; 2. Mark DeVoto, "Paris, 1918-45"; 3. Douglas Jarman, "Vienna after the Empire"; 4. Stephen Hinton, "Germany, 191845"; 5. John C.G. Waterhouse, "Italy from the first World War to the Second"; 6. Michael Beckerman and Jim Samson, "Eastern Europe, 1918-45"; 7. Laurel E. Fay, "The USSR"; 8. Knud Ketting, "The Nordic Countries, 1918-45"; 9. Stephen Banfield, "England, 1918-45"; 10. Carol J. Oja, "The USA, 1918-45"; 11. Gerard Béhague, "The Hispanic World, 1918-45"; 12. Andrew Clements, "Western Europe, 1945-70"; 13. Detlef Gojowy, "Russia and Eastern Europe, 1945-70"; 14. William Brooks, "The Americas, 1945-70"; 15. Keith Potter, "The Current Musical Scene"; 16. Michael Tenzer, "Western Music in the Context of World Music."

14For example, the "Société Nationale de Musique" is indexed under "Paris" in Volume 2. 
This collection of sixteen articles aims to cover music from 1918 to the present, a period that, according to Robert P. Morgan, can be referred to as 'modern,' because "we feel it to be, even when viewed as a whole, in some sense distinctly our own" (p. 1). Terming music written seventy-five years ago 'modern' might seem somewhat anachronistic, especially when one considers both the pace and heteronomous nature of musical developments in the interim, yet 'modern' remains in fairly common usage in describing the music of this era, and perhaps is no more of a stretch of meaning than some of the other terms used in describing the periods of musical history. Perhaps the more accurate title, "Music Since the First World War," was not chosen to avoid confusion with Arnold Whittall's book of the same name.

Within the period covered by Modern Times, the focus is disproportionately on the earliest part, 1918-45; ten of the book's sixteen articles deal with regional musical developments in Europe, the USSR, and the USA from the end of the first world war to the end of the second. Only three articles cover the next twenty-five years, the period 1945-1970, but the regional canvas is broader and more generalized, covering Eastern Europe and Russia, Western Europe, and "The Americas," which means, for the most part, the USA. There is very little Canadian content. The rationale for this is perhaps to be found in Stanley Sadie's preface to the Music and Society series, of which this book is the eighth (and last). He writes: "These books do not attempt to treat musical history comprehensively. Their editors have chosen for discussion the musical centres that they see as the most significant and the most interesting; many lesser ones inevitably escape individual discussion ..." (p. $x$ ). This approach works best in the ten chapters (2-11) dealing with the 1918-45 period, where the topical and regional parameters are clearly defined. The following chapters, in spite of the claims in the preface, do attempt to treat larger regions comprehensively, and, at least in the case of "The Americas, 1945-70," and "The Current Musical Scene," do so less successfully.

Only one of the sixteen chapters focuses on music written in the past quarter-century. The inherent challenges in writing about more recent musical trends are tangible; there is much raw information (including hyperbole) to sort through, and any perspective to be gained through the passage of time is minimal. However, the multi-authored format of Modern Times affords the possibility of more varied viewpoints on recent events than the sole 'modern' perspective offered by Keith Potter. "The Current Musical Scene" leads us from the mid- to late-1960s demise of the avant-garde, which he calls "the second period of 'high modernism' in this century" (p. 350), to pluralism, which he calls "an apt description of current compositional uncertainties and, paradoxically, of the fragmentation of audiences for music of many kinds as well as the 'crossover' phenomenon that joins styles and aesthetics in unlikely combinations" (p. 350). Potter offers an interesting and informed discussion of works by some established composers writing in this period, as well as some of the more recently emerging ones, which include Pärt, Schnittke, Rzewski, Adams, Reich, Glass, Laurie Anderson, del Tredici, Taverner, Ferneyhough, Andriessen, Kagel, and Górecki, whose remarkable ascent in the British pop 
charts in early 1993 through his Third Symphony is briefly mentioned, but given no analysis. Was this a freak occurrence, or part of a trend?

Potter's focus is on Eastern and Western Europe, and the USA; composers from other regions of the world, including South America, Australia, Africa, the Middle East, Asia, and Canada, are unfortunately omitted. Are these all examples of the 'lesser' musical centres referred to in the preface? And it is not just regions that are marginalized; aside from Laurie Anderson, no female composers are even named! This seems a surprising oversight as the past twenty-five years have surely seen more women composers rise to prominence than in any earlier period of music history. Why is this not examined? There is very little discussion of electronic music, aside from its role in some of the work being done at IRCAM in Paris, while mixed media, theatre, 'new-age' and other popular-influenced 'serious' music are given only incidental or no coverage.

Michael Tenzer's "Western Music in the Context of World Music" discusses several of the composers mentioned in Potter's article, and even some of the same pieces, but covers much broader historical, geographical, and sociological territory. Tenzer concentrates on western composers who have been influenced by non-western sources, such as Partch, Harrison, Cage, and Nancarrow. Colin McPhee, who is listed as American, is mentioned, but his ties to Canada (he was born here!) are not. Tenzer's historical overview is perhaps too diffuse for the context of this book; in the fourth section of his article, ambitiously entitled "Cross-Cultural Influences until the Mid-Twentieth Century" (pp. 396-400), he cites 'exotic' or 'nationalistic' qualities in the music of Debussy, Liszt, Verdi, and even Beethoven and Mozart.

If Canadian composers are essentially unrepresented in the articles discussed thus far, how are they represented in the remaining chapters? The only article that attempts to cover Canadian music is William Brooks' "The Americas, 1945-70," which also tries to cover the music of Central and South America during this period, but the focus is squarely on the USA. Although there are several references to Canadian composers, they are usually mentioned in lists that do not tell us very much about them. For example: "Berio's 'Sinfonia' is commonly taken as a watershed ... but other composers explored historicism and collage more thoroughly and systematically-John Beckwith, George Crumb, Lukas Foss, Edwin London, George Rochberg, and Loren Rush, to name a few" (p. 325). Or: "Indeed, (Babbitt's) efforts to extend row techniques to other compositional domains were closely paralleled by European serialists like Pierre Boulez and Karlheinz Stockhausen, as well as Americans like Ernst Krenek and Serge Garant" (p. 333). The best examples of American serialists he can come up with are a transplanted German and a Canadian? To the author's credit, the article is a well-researched summary of post-WWII developments in the USA, with occasional references to activities beyond its borders, but the problem of cultural marginalization that has long existed for the non-American countries in the Americas persists. ${ }^{15}$ It seems a

15 John Beckwith and Dorith R. Cooper, eds. Hello Out There! Canada's New Music in the World, 
form of cultural narcissism to define a larger region (the Americas) in terms of the author's own (the USA).

The most successful articles for me are the ten that focus (usually) on smaller regions, covering the 1918-1945 period. Each is informative, not only to the 'general reader' (to which, according to Stanley Sadie's preface (p. x), this series is aimed), but to the specialist as well. The authors are well-chosen; each is a scholar of considerable expertise in the area they write on. These ten chapters, as well as the two that focus on western and eastern European (and the USSR) music during 1945-70, each give a thorough and balanced account of regional musical activity during a specific time period. The regional scope varies greatly within these articles; Mark DeVoto's "Paris, 1918-45," and Douglas Jarman's "Vienna after the Empire," are the most narrow in focus, but also two of the highlights of this collection. On the other hand, Knud Ketting's "The Nordic Countries, 1918-45," and especially Gerard Béhague's "The Hispanic World, 1918-45," cover much larger regions, but in spite of this, are still able to do so in a fairly comprehensive and even-handed way.

There remains a need for a book that applies this kind of detailed, regional approach to more recent music as well. I am not convinced that Canadian music as a whole inevitably parallels Argentinean, Israeli, English, or even American, to name a few examples, although there are undoubtedly many similarities in any of these comparisons. Nor am I even certain that the new music scene in different regions within Canada (or any of these countries, for that matter) is necessarily homogeneous. The oft-cited pluralism in the music of the past twenty-five years, as well as our chronological proximity to this music, make deciding which musical centres (or movements) are the most "significant" and "interesting," and which are the "lesser ones" (to quote again from the preface, p. $x$ ), extremely difficult; perhaps there would be value in a pluralistic approach to writing on this music as well.

Clark Ross

Élisabeth Gallat-Morin. Jean Girard, musicien en Nouvelle-France, Bourges, 1696-Montréal, 1765. Paris : Les éditions du Septentrion, 1993. 352 p. ISBN 2-921114-87-9.

Le 9 octobre 1724, débarquait en Nouvelle-France un ecclésiastique français de 28 ans. Fils d'un boulanger de Bourges, Jean Girard avait reçu sa formation générale et musicale (chant et serpent) à la maîtrise de la Sainte-Chapelle de Bourges, puis avait fréquenté le séminaire de Saint-Sulpice à Paris où on le rapporte maître de chant en janvier 1724. Dans l'entourage des sulpiciens de Montréal, Girard allait se consacrer, pendant près de 40 ans, à l'enseignement dans les petites écoles de la paroisse et au service de la musique d'église, tout

1950-85 (Toronto: Institute for Canadian Music, 1988), contains many papers on cultural marginalization. Two that are particularly relevant are "Two Cultural 'Marginalities,' Argentina and Canada" (pp. 70-73), by Mariano Etkin, and "A 'Failure' Revisited: New Canadian Music in Recent Studies and Reference Works" (pp. 114-22), by John Beckwith. 